\title{
A study of the role of e-commerce implementation on electronic banking development
}

\author{
Fatemeh Nehzat $^{\mathrm{a}^{*}}$, Hamid Maleki ${ }^{\mathrm{a}}$ and Abdollah Naami ${ }^{\mathrm{b}}$
}

${ }^{a}$ Department of Management, Payame NoorUniversity, Alborz, Iran

${ }^{b}$ Department of Management, Tehran South Branch, Islamic Azad University, Tehran, Iran

\section{H R O N I C L E A B S R A C T}

Article history:

Received January 20, 2014

Accepted 30 August 2014

Available online

August 302014

E-business

Electronic banking

Knowledge

\begin{abstract}
This paper presents an empirical investigation to study the role of e-commerce implementation of development of electronic banking. The study determines the effects of four factors, management knowledge, technological issues, financial and socio-economic factors on development of e-banking in city of Tehran, Iran. The study designs a questionnaire in Likert scale and distributes it among 96 randomly selected managers who work for Bank Saderat Iran. Cronbach alpha has been calculated as 0.89 , which is well above the minimum acceptable level. Using Pearson correlation as well as stepwise regression technique, the study has determined that management, social and economic factors influence the most on electronic banking development.
\end{abstract}

\section{Introduction}

During the past few years, there have been significant changes on banking industry (Chaffey, 2002; Lichtenstein \& Williamson, 2006). Many bank customers are now able to do their daily banking activities using their home/work internet. They are even able to do their banking businesses using mobile devices (Sathye, 1999; Lassar et al., 2005). Therefore, it is important to learn more about the effects of various factors on development e-banking. Kolodinsky et al. (2004) explored factors, which could influence on the adoption or intention to adopt three e-banking technologies. Using a Federal Reserve Board commissioned data set, they determined that relative advantage, complexity/simplicity, compatibility, observability, risk tolerance, and product involvement were associated with adoption. Income, assets, education, gender and marital status, and age could also influence on adoption of e-banking. They reported that adoption could change over time, but the effects of other factors on adoption did change. Akinci et al. (2004) reported substantial differences between the demographic profiles and users' behaviors and non-users in internet banking. Laforet and Li (2005) studied the market status for online/mobile banking in China and reported that Chinese online and mobile bank users were predominantly males, not necessarily young and highly educated, in contrast with the electronic bank users in the West.

*Corresponding author. Tel: +989192511737

E-mail addresses: nehzat.fatima@gmail.com (F. Nehzat)

(c) 2014 Growing Science Ltd. All rights reserved. doi: $10.5267 / \mathrm{j} . \mathrm{ms} 1.2014 .8 .032$ 
Pikkarainen et al. (2004) reported that perceived usefulness and information on online banking on the Web site were the main factors influencing online-banking acceptance. Wan et al. (2005) studied factors that impacted Hong Kong bank customers' adoption of four major banking channels, i.e. branch banking, ATM, telephone banking, and internet banking. They reported that automated telling machine ATM was the most frequently adopted channel, followed by internet banking and branch banking, and telephone banking was the least frequently adopted channel. According to Rexha et al. (2003), customer satisfaction, trust, and the use of electronic have a positive impact on the corporate clients' commitment towards their bank. Karjaluoto et al. (2002) investigated the impact of various factors influencing on attitude formation towards Internet banking in Finland. They tried to determine those factors that affect the formation of attitude towards Internet banking on the one hand, and their relationship with the implementation of online banking services, on the other.

\section{The proposed study}

This paper presents an empirical investigation to study the role of e-commerce implementation of development of electronic banking. The study determines the effects of four factors, management knowledge, technological issues, financial and socio-economic factors on development of e-banking in city of Tehran, Iran. Fig. 1 shows the structure of the proposed study,

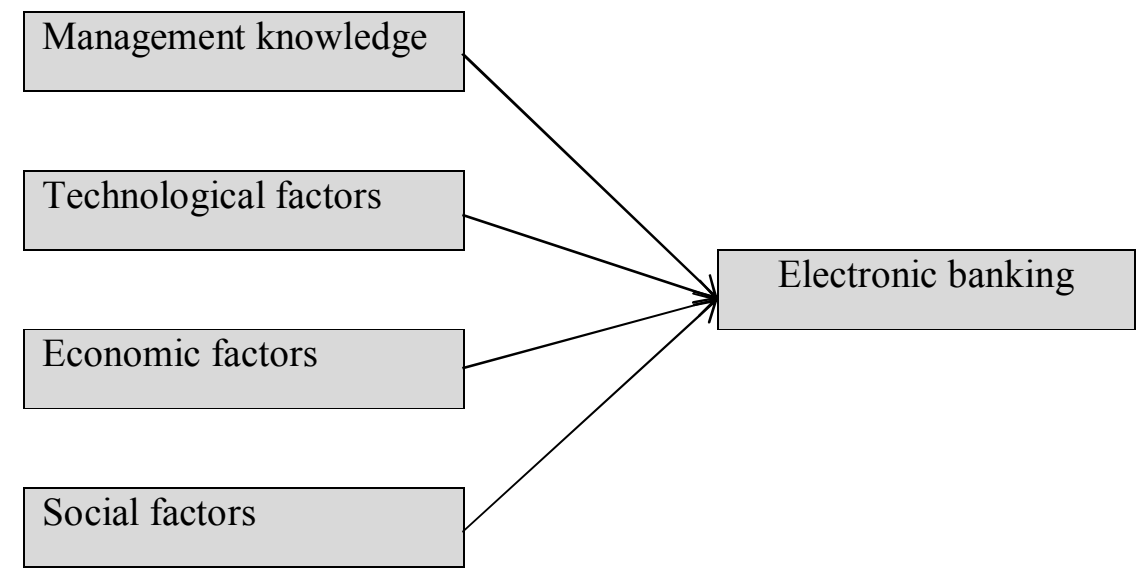

Fig. 1. The proposed study

According to Fig. 1, the following four hypotheses are considered for the study of this paper,

1. There is a meaningful relationship between the level of banks' managers and development of electronic banking.

2. There is a meaningful relationship between technological factors and development of electronic banking.

3. There is a meaningful relationship between economic factors and development of electronic banking.

4. There is a meaningful relationship between social factors and development of electronic banking.

The population of this study includes all managers who work for different Bank Saderat branches in city of Tehran, Iran. The sample size is calculated as follows, 


$$
N=Z_{\alpha / 2}^{2} \frac{p \times q}{e^{2}},
$$

where $N$ is the sample size, $p=1-q$ represents the probability, $z_{\alpha / 2}$ is CDF of normal distribution and finally $\varepsilon$ is the error term. For our study we assume $p=0.5, z_{\alpha / 2}=1.96$ and $e=0.05$, the number of sample size is calculated as $N=98$. The propsoed study designs a questionnaire in Likert scale and distribites it among 100, 50 men and 50 women, randomly selected managers. Cronbach alpha has been calculated as 0.89 , which is well above the minimum acceptable level. Fig. 2 demonstares personal characteristics of the participants.

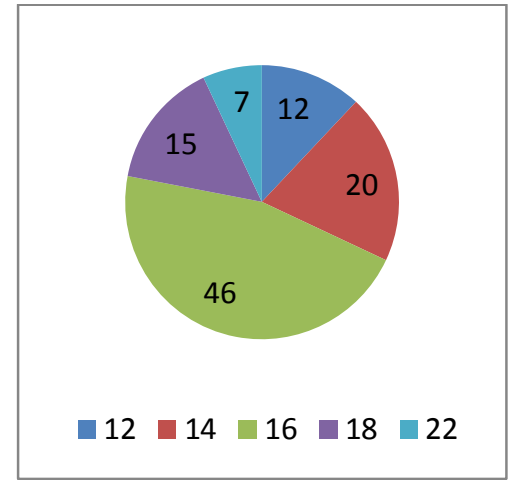

Years of education

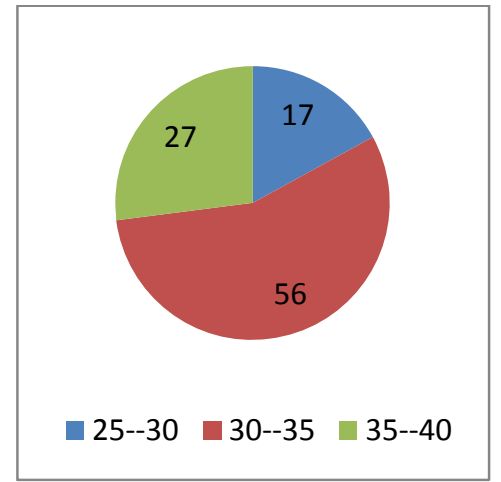

Age

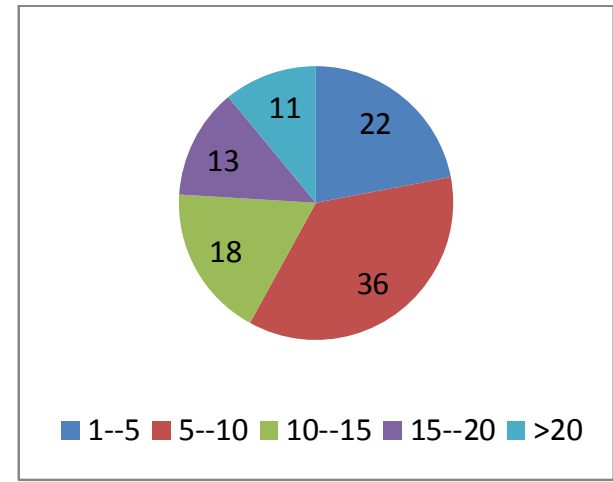

Years of job experiences

Fig. 2. Personal characteristics of the participants

According to the results of Fig. 2, 70\% of the participants hold, at least, a bachelor degree of science. In addition, most participants were middle age people and maintained good job experiences. The implementation of Kolmogorov-Smirnov test has indicated that all components of the survey are normally distributed.

\section{The results}

In this section, we present details of the results of the implementation of Pearson correlation test as well as stepwise regression analysis. Table 1 shows the summary of Pearson correlation test.

\section{Table 1}

The summary of Pearson correlation test for examining four hypotheses of the survey

\begin{tabular}{lccc}
\hline Hypothesis & Pearson ratio & Sig. & Result \\
\hline 1 & 0.431 & 0.01 & Confirmed \\
2 & 0.293 & 0.00 & Confirmed \\
3 & 0.341 & 0.02 & Confirmed \\
4 & 0.375 & 0.000 & Confirmed \\
\hline
\end{tabular}

According to the results of Table 1, there are positive and meaningful relationships between all four factors and development of electronic banking. The highest relationship was associated between the level of banks' managers and development of electronic banking followed by a positive relationship between social factors and electronic banking. Table 2 shows details of stepwise regression technique. 
Table 2

The summary of stepwise regression technique

\begin{tabular}{lccccc}
\hline & $\begin{array}{c}\text { Standard } \\
\text { Coefficient }\end{array}$ & Standard error & $\begin{array}{c}\text { Standard } \\
\text { coefficient }\end{array}$ & t-value & Sig. \\
\hline Intercept & 34.418 & 2.135 & & 10.294 & .000 \\
Managers' knowledge & .563 & .390 & .414 & 3.851 & .000 \\
Socio-economic factors & .384 & .271 & .358 & 3.417 & .013 \\
Financial factors & .305 & .218 & .293 & 3.269 & .002 \\
\hline Adjusted R-Square $=0.239$ & & & & &
\end{tabular}

\section{Conclusion}

In this paper, we have presented an empirical investigation to determine the effects of different factors on development of e-banking in one of Iranian banks named Bank Saderat in city of Tehran, Iran. The study has implemented Pearson correlation as well as Stepwise regression test and found that managers' knowledge is the most important factor for development of e-banking followed by socio-economic and financial factors.

\section{Acknowledgement}

The authors would like to thank the anonymous referees for constructive comments on earlier version of this paper.

\section{References}

Akinci, S., Aksoy, S., \& Atilgan, E. (2004). Adoption of internet banking among sophisticated consumer segments in an advanced developing country. International Journal of Bank Marketing, 22(3), 212-232.

Chaffey, D. (2002). E-Business and E-commerce Management. Prentice-Hall, NJ.

Karjaluoto, H., Mattila, M., \& Pento, T. (2002). Factors underlying attitude formation towards online banking in Finland. International Journal of Bank Marketing, 20(6), 261-272.

Kolodinsky, J. M., Hogarth, J. M., \& Hilgert, M. A. (2004). The adoption of electronic banking technologies by US consumers. International Journal of Bank Marketing, 22(4), 238-259.

Laforet, S., \& Li, X. (2005). Consumers' attitudes towards online and mobile banking in China. International Journal of Bank Marketing, 23(5), 362-380.

Lassar, W. M., Manolis, C., \& Lassar, S. S. (2005). The relationship between consumer innovativeness, personal characteristics, and online banking adoption. International Journal of Bank Marketing, 23(2), 176-199.

Lichtenstein, S., \& Williamson, K. (2006). Understanding consumer adoption of internet banking: an interpretive study in the Australian banking context. Journal of Electronic Commerce Research, 7(2), 50-66.

Pikkarainen, T., Pikkarainen, K., Karjaluoto, H., \& Pahnila, S. (2004). Consumer acceptance of online banking: an extension of the technology acceptance model. Internet Research, 14(3), 224235.

Rexha, N., Kingshott, R. P. J., \& Aw, A. S. S. (2003). The impact of the relational plan on adoption of electronic banking. Journal of Services Marketing,17(1), 53-67.

Sathye, M. (1999). Adoption of internet banking by Australian consumers: an empirical investigation. International Journal of bank marketing, 17(7), 324-334.

Wan, W. W., Luk, C. L., \& Chow, C. W. (2005). Customers' adoption of banking channels in Hong Kong. International Journal of bank marketing, 23(3), 255-272. 